\title{
Clinical outcomes of patient navigation performed by nurses in the oncology setting: an integrative review
}

\author{
Resultados clínicos da navegação de pacientes realizada por enfermeiros no cenário da oncologia: revisão integrativa
}

Resultados clínicos de la navegación del paciente realizada por enfermeras en el escenario de oncología: revisión integrativa

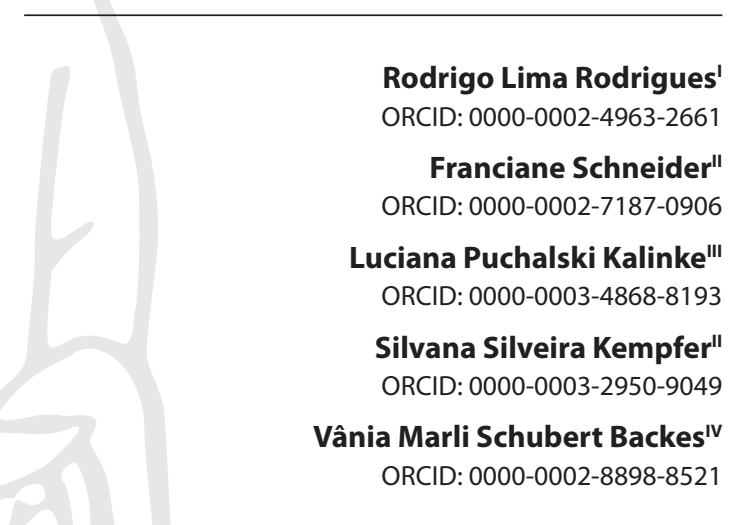

'Centro de Pesquisas Oncológicas. Florianópolis, Santa Catarina, Brazil.

"Universidade Federal de Santa Catarina. Florianópolis, Santa Catarina, Brazil.

III Universidade Federal do Paraná. Curitiba, Paraná, Brazil.

"Universidade Federal da Bahia. Salvador, Bahia, Brazil.

How to cite this article:

Rodrigues RL, Schneider F, Kalinke LP, Kempfer SS, Backes VMS. Clinical outcomes of patient navigation performed by nurses in the oncology setting: an integrative review. Rev Bras Enferm. 2021;74(2):e20190804. doi: http://dx.doi.org/10.1590/0034-7167-2019-0804

\section{Corresponding author:}

Franciane Schneider

E-mail: franciane_06@yahoo.com.br

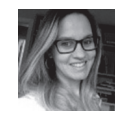

EDITOR IN CHIEF: Antônio José de Almeida Filho ASSOCIATE EDITOR: Priscilla Broca

Submission: 03-11-2020

Approval: 10-18-2020

\section{ABSTRACT}

Objective: to evidence the clinical outcomes of navigation performed by nurses in cancer patients. Methods: this is an integrative literature review with collection in MEDLINE via PUBMED, LILACS, Web of Science, Scopus, and CINAHL databases. The final sample consisted of seven studies. The data were analyzed and presented descriptively. Data related to clinical outcomes were compiled and described in full. The Agency for Healthcare Research and Quality categorization was used to assess the level of evidence. Results: the clinical outcomes demonstrated were decreased distress, anxiety and depression, improved control and management of symptoms, improved physical conditioning, improved quality and continuity of care, improved quality of life, reduced time to start treatment. Final considerations: there is research that shows better clinical outcomes in cancer patients through navigation by nurses across the continuum of health care.

Descriptors: Patient Navigation; Oncology Nursing; Treatment Outcome; Evidence-Based Nursing; Outcome Assessment (Health Care).

\section{RESUMO}

Objetivo: evidenciar os resultados clínicos da navegação realizada por enfermeiros no paciente com câncer. Métodos: revisão integrativa da literatura, com coleta nas bases de dados MEDLINE via PUBMED, LILACS, Web of Science, Scopus e CINAHL. A amostra final foi composta por sete estudos. Os dados foram analisados e apresentados descritivamente. Dados relacionados aos resultados clínicos foram compilados e descritos na íntegra. Utilizou-se a categorização da Agency for Healthcare Research and Quality para avaliação do nível de evidência. Resultados: os resultados clínicos demonstrados foram diminuição do sofrimento, ansiedade e depressão, melhora no controle e manejo dos sintomas, melhora no condicionamento físico, melhora na qualidade e continuidade dos cuidados, melhora na qualidade de vida, redução do tempo para o início do tratamento. Considerações finais: há pesquisas que evidenciam melhores resultados clínicos no paciente com câncer por meio da realização da navegação pelo enfermeiro em todo o continuum de assistência à saúde. Descritores: Navegação de Pacientes; Enfermagem Oncológica; Resultado do Tratamento; Enfermagem Baseada em Evidências; Avaliação de Resultados (Cuidados de Saúde).

\section{RESUMEN}

Objetivo: destacar los resultados clínicos de la navegación realizada por enfermeras en pacientes oncológicos. Métodos: revisión integradora de la literatura, con recogida en las bases de datos MEDLINE vía PUBMED, LILACS, Web of Science, Scopus y CINAHL. La muestra final consistió en siete estudios. Los datos fueron analizados y presentados de forma descriptiva. Los datos relacionados con los resultados clínicos se recopilaron y describieron en su totalidad. Se utilizó la categorización de la Agency for Healthcare Research and Quality para evaluar el nivel de evidencia. Resultados: los resultados clínicos demostrados fueron disminución del sufrimiento, ansiedad y depresión, mejor control y manejo de los síntomas, mejor acondicionamiento físico, mejor calidad y continuidad de la atención, mejor calidad de vida, menor tiempo para iniciar el tratamiento. Consideraciones finales: existen estudios que muestran mejores resultados clínicos en pacientes con cáncer a través de la navegación por enfermeras a lo largo del continuo de la atención de salud

Descriptores: Navegación de Pacientes; Enfermería Oncológica; Resultado del Tratamiento; Enfermería Basada en la Evidencia; Evaluación de Resultado (Atención de Salud). 


\section{INTRODUCTION}

The first patient navigation program was developed in 1990 in the State of New York, United States of America, by doctor Harold Freeman. The main objective of the program was to eliminate socioeconomic, sociocultural, psychological, communication and bureaucratic barriers in the course of patient care, covering the entire health continuum process, which includes prevention, early detection, diagnosis, treatment, and end of life care. After its implementation, there was an improvement in education and access to early diagnosis and treatment, increasing the survival rate of patients with breast cancer ${ }^{(1)}$. After the development of navigation programs, the figure of nurse navigators emerged in the oncology setting ${ }^{(2)}$.

Navigation is commonly used in the United States and Canada, in order to direct the therapy of cancer patients and increase the chances of adherence to the proposed treatment. Research show evidence regarding the effectiveness of navigation in early diagnosis and in the initial stage of the disease, in effective participation and increased patient compliance with treatments, in reducing delays in starting cancer treatments, and in improving clinical outcomes after cancer diagnosis ${ }^{(3)}$. In this way, many health institutions are implementing patient support programs, involving mainly nurses, who navigate patients in different settings of health systems ${ }^{(4)}$. Navigators are in charge of assessing patients' individual needs and developing a care plan, together with them, in order to overcome the barriers that hinder access to high quality care ${ }^{(5)}$.

The navigation of patients performed by nurses is described as an intervention to reduce delays in accessing health services and providing personalized service throughout the treatment trajectory. It is a patient-centered care delivery model. The focus of navigation is to promote a timely movement and effective guidance of a patient through a continuum of health care that is often complex ${ }^{(1)}$. Thus, there is a need to obtain professionals with specific skills directed to the art of navigation, emphasizing the role of nurses working in oncology.

In oncology, nurses, over the years, have been developing their role with a focus on the coordination of care, as well as on the education of patients and their families, from diagnosis to end of treatment or end of life care. They are professionals with the necessary skills and attitudes to perform the navigation of cancer patients. They have clinical knowledge related to the disease, types of treatments and possible side effects. They support patients and their families in the decision-making process and have the expertise to work in collaboration with the other multidisciplinary team members, forming a link between professionals, patients and family members ${ }^{(2)}$.

It is known that many times cancer patients face difficulties that have important consequences during the course of their treatment, initially by screening, followed by diagnosis, which is often not performed early, culminating in late treatments, which considerably reduces the chances of cure and survival ${ }^{(6-7)}$. A study ${ }^{(7)}$ carried out in the United States of America (USA), which assessed the performance of nurse navigators in caring for cancer patients, pointed out that the patients' perception of treatment improved significantly with the work of these professionals. Moreover, it described how much patients are exposed to feelings such as anxiety, fear, and confusion during the course of treatment, and how navigating by nurses made them feel safer and more involved in their care, as they had knowledge about future steps treatment and how cancer could affect their lives ${ }^{(7)}$.

Navigation is an expanding service model and contributes to the trajectory of care for cancer patients. However, at the national level, there is still no clarity about the role of these professional navigators. The navigation performed by nurses is considered an important differential in oncology services in Brazil, as it can bring benefits in the continuum of health care ${ }^{(8)}$. However, it is noted that currently there is no universal consensus on what constitutes navigation services and there is insufficient evidence on the effectiveness of these programs in the clinical outcomes of cancer patients ${ }^{(2)}$.

Considering the scenario above, the present research had as guiding question: does navigation performed by nurses provide better clinical outcomes for cancer patients?

\section{OBJECTIVE}

To evidence the clinical outcomes of navigation performed by nurses in cancer patients.

\section{METHODS}

\section{Type of study and methodological procedures}

This is an integrative review of the scientific literature that was carried out through the following steps: 1) research question and objective definition, together with the review protocol development; 2 ) inclusion and exclusion criteria definition and choice of databases; 3 ) sample selection; 4) inclusion of previous studies; 5) analysis of previous results, identifying differences and conflicts; 6) discussion and analysis of the final results; 7) study synthesis presentation $^{(9)}$.

\section{Data collection and organization}

A data search was performed in January 2019 in Medical Literature Analysis and Retrieval System Online (MEDLINE) - via National Library of Medicine - National Institutes of Health (PUBMED), Latin American \& Caribbean Literature in Health Sciences (LILACS), Web of Science, SciVerseScopus (Elsiever) and Cumulative Index to Nursing and Allied Health Literature (CINAHL) databases.

Studies that contained search terms listed anywhere in the document, published in full, in any language, with no time frame and that answered the research question were included. Editorials, letters, expert comments, summaries of annals, theses, dissertations, conclusion papers, official documents of national and international programs, books, literature reviews and duplicate studies were excluded.

The search strategy used the descriptors (controlled and uncontrolled) from the Medical Subject Headings Section (MeSH) and Health Sciences Descriptors (DeCS - Descritores em Ciências da Saúde) as follows: oncology nursing, patient navigation, 
treatment outcome, evidence-based nursing, outcome assessment (healthcare), outcomes assessment, case management and continuity of patient care; and the keywords: nurse navigator and nurse navigators. They were combined with each other by the Boolean operators "AND" and/or "OR", as shown in Chart 1:

The EndNote Web ${ }^{\circ}$ software was used to manage data and eliminate duplicate studies. Subsequently, the selection of studies took place in two stages: 1 ) reading titles and abstracts, in order to identify the relationship with the research question as well as with the inclusion and exclusion criteria adopted; 2) critical assessment and full reading of pre-selected studies, excluding those that did not meet the inclusion criteria.

Figure 1 (Flowchart) details the process of identification, inclusion and exclusion of studies and the reasons for exclusions after assessment.

Chart 1 - Search strategies in databases

\begin{tabular}{|c|c|}
\hline $\begin{array}{l}\text { MEDLINE via } \\
\text { PUBMED }\end{array}$ & $\begin{array}{l}\text { "oncology nursing" OR ("oncology" AND "nursing") } \\
\text { OR "oncology nursing" AND ("patient navigation" } \\
\text { OR ("patient" AND "navigation") OR"patient } \\
\text { navigation") OR ("nurses" OR "nurse") OR ("nurses" } \\
\text { OR "nurse" AND "navigators") AND ("treatment } \\
\text { outcome" OR ("treatment" AND "outcome") OR } \\
\text { "treatment outcome") OR ("evidence-based } \\
\text { nursing" OR ("evidence-based" AND "nursing") } \\
\text { OR "evidence-based nursing" OR ("evidence" } \\
\text { AND "based" AND "nursing") OR "evidence based } \\
\text { nursing") OR ("outcome assessment (health care)" } \\
\text { OR ("outcome" AND "assessment" AND ("health" } \\
\text { AND "care") OR "outcome assessment (health care)" } \\
\text { OR ("outcome" AND "assessment") OR "outcome } \\
\text { assessment") AND ("delivery of health care" OR } \\
\text { ("delivery" AND "health" AND "care") OR "delivery } \\
\text { of health care" OR ("health" AND "care") OR "health } \\
\text { care") OR ("outcome assessment (health care)" OR } \\
\text { ("outcome" AND "assessment" AND ("health" AND } \\
\text { "care)") OR "outcome assessment (health care)" } \\
\text { OR ("outcomes" AND "assessment") OR "outcomes } \\
\text { assessment") OR ("case management" OR ("case" } \\
\text { AND "management") OR "case management") OR } \\
\text { ("continuity of patient care" OR ("continuity" AND } \\
\text { "patient" AND "care") OR "continuity of patient } \\
\text { care") }\end{array}$ \\
\hline LILACS & $\begin{array}{l}\text { (Oncology Nursing) AND (Patient Navigation } \\
\text { OR Nurse Navigator OR Nurse Navigators) AND } \\
\text { (Treatment outcome OR Evidence-Based Nursing } \\
\text { OR Outcome Assessment (Health Care) OR } \\
\text { Outcomes Assessment OR Case Management OR } \\
\text { Continuity of Patient Care) }\end{array}$ \\
\hline Web of Science & $\begin{array}{l}\text { (Oncology Nursing) AND (Patient Navigation } \\
\text { OR Nurse Navigator OR Nurse Navigators) AND } \\
\text { (Treatment outcome OR Evidence-Based Nursing } \\
\text { OR Outcome Assessment (Health Care) OR } \\
\text { Outcomes Assessment OR Case Management OR } \\
\text { Continuity of Patient Care) }\end{array}$ \\
\hline Scopus (Elsiever) & $\begin{array}{l}\text { ("Oncology Nursing" AND "Patient Navigation" } \\
\text { OR "Nurse Navigator" OR "Nurse Navigators" AND } \\
\text { "Treatment Outcome" OR "Evidence-Based Nursing" } \\
\text { OR "Outcome Assessment (Health Care)" OR } \\
\text { "Outcomes Assessment" OR "Case Management" } \\
\text { OR "Continuity of Patient Care") }\end{array}$ \\
\hline CINAHL & $\begin{array}{l}\text { Oncology Nursing AND (Patient Navigation OR } \\
\text { Nurse Navigator OR Nurse Navigators) AND } \\
\text { (Treatment outcome OR Evidence-Based Nursing } \\
\text { OR Outcome Assessment (Health Care) OR } \\
\text { Outcomes Assessment OR Case Management OR } \\
\text { Continuity of Patient Care) }\end{array}$ \\
\hline
\end{tabular}

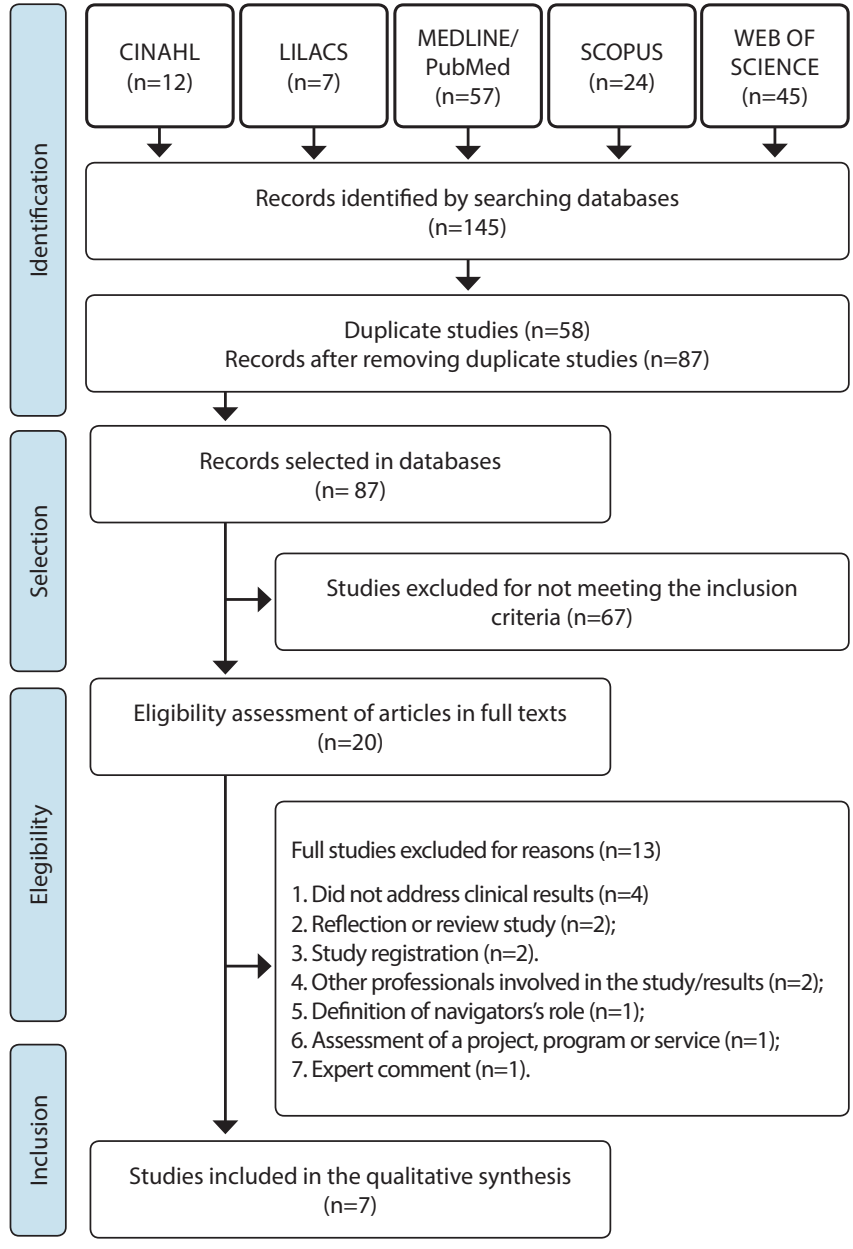

Figure 1 - Research flowchart in the scientific literature and study selection criteria

\section{Data analysis}

The studies were characterized using title, authors, year of publication, country of origin, level of evidence (AHRQ), study design, profile of participants, intervention, outcomes and main conclusions. The data extracted from the studies were analyzed and presented in a descriptive manner. With the complete reading of the selected studies, the clinical outcomes of the navigation of cancer patients performed by nurses were identified. Afterwards, these data were compiled and described in full, according to the evidence presented by them.

For the hierarchical classification of evidence, the categorization of the Agency for Healthcare Research and Quality (AHRQ) of the United States of America was used. Thus, the studies were assessed for the quality of the evidence and classified as: level 1, the evidence comes from a systematic review or meta-analysis of relevant randomized controlled clinical trials or from clinical guidelines based on systematic reviews of randomized controlled clinical trials; level 2, evidence derived from at least one well-designed randomized controlled clinical trial; level 3, evidence obtained from well-designed clinical trials without randomization; level 4, evidence from well-designed cohort studies and control cases; level 5, evidence from systematic review of descriptive and qualitative studies; level 6, evidence derived from a single descriptive or 
qualitative study; level 7, evidence from the opinion of authorities and/or expert committee reports ${ }^{(10)}$.

\section{RESULTS}

The geographic distribution of the selected publications was concentrated in the United States of America (USA) (57\%), followed by Canada (14\%), South Korea (14\%), and Denmark (14\%). The predominant language was English. The year of publication varied between 2006 and 2017, with the highest publication in 2011 and 2015, with two studies each year, followed by 2006, 2010, and 2017 with one study each year, respectively.

The characteristics of the seven studies ${ }^{(11-17)}$ included in this review are shown in Chart 2.

Chart 2 - Characteristics of selected studies

\begin{tabular}{|c|c|c|c|c|}
\hline $\begin{array}{l}\text { Title, } \\
\text { Authors }\end{array}$ & $\begin{array}{l}\text { Year, country, } \\
\text { level of evidence } \\
\text { (AHRQ) }\end{array}$ & $\begin{array}{l}\text { Outlining/ profile } \\
\text { of participants }\end{array}$ & Intervention & Outcomes/main conclusions \\
\hline $\begin{array}{l}\text { Implementing the role } \\
\text { of patient-navigator } \\
\text { nurse at a university } \\
\text { hospital centre } \\
\text { Fillion and } \\
\text { collaborators }^{(11)}\end{array}$ & $\begin{array}{l}2006, \\
\text { Canada, } \\
\text { VI }\end{array}$ & $\begin{array}{l}\text { Qualitative, } \\
\text { descriptive and } \\
\text { longitudinal study } \\
\text { Head and neck } \\
\text { cancer, family } \\
\text { members, health } \\
\text { professionals } \\
\text { and care network } \\
\text { partners }\end{array}$ & $\begin{array}{l}\text { Implementation of the role of } \\
\text { nurse navigators }\end{array}$ & $\begin{array}{l}\text { Patients reported improvement in } \\
\text { communication, health education, adaptation } \\
\text { to the health and disease process, better } \\
\text { understanding of the disease and coping with } \\
\text { treatment. Navigators also encouraged a healthy } \\
\text { lifestyle and reduced anxiety related to fear of } \\
\text { recurrence of the disease. } \\
\text { The main impact was on improving the } \\
\text { quality and continuity of care, both clinically } \\
\text { and relationally. Nurse navigators facilitates } \\
\text { the process of adaptation to the process of } \\
\text { illness and treatment, as well as improves } \\
\text { interdisciplinary work and continuity of care. }\end{array}$ \\
\hline $\begin{array}{l}\text { The role of the } \\
\text { oncology nurse } \\
\text { navigator in distress } \\
\text { management of adult } \\
\text { inpatients with cancer: } \\
\text { a retrospective study } \\
\text { Swanson and } \text { Koch }^{(12)}\end{array}$ & $\begin{array}{l}2010 \\
\text { USA, } \\
\text { VI }\end{array}$ & $\begin{array}{l}\text { Retrospective } \\
\text { study } \\
\text { (medical records) } \\
\text { Gastrointestinal } \\
\text { cancer; lung } \\
\text { cancer; breast } \\
\text { cancer; and } \\
\text { leukemias and } \\
\text { lymphomas }\end{array}$ & $\begin{array}{l}\text { Assessment and follow-up } \\
\text { with nurse navigators }\end{array}$ & $\begin{array}{l}\text { The presence of nurse navigators did not } \\
\text { significantly affect the stress levels of hospitalized } \\
\text { patients, despite presenting an average stress } \\
\text { reduction. A decrease in stress was observed in } \\
\text { rural patients when compared to patients in the } \\
\text { urban area. Patients who received more than three } \\
\text { visits from navigators had a greater reduction in } \\
\text { stress than those with less than three visits. On } \\
\text { average, the intervention of navigators showed a } \\
\text { reduction in the scores of distress of all patients. }\end{array}$ \\
\hline $\begin{array}{l}\text { Effects of nurse } \\
\text { navigators on health } \\
\text { outcomes of cancer } \\
\text { patients } \\
\text { Lee and collaborators }{ }^{(13)}\end{array}$ & $\begin{array}{c}2011, \\
\text { South Korea, } \\
\text { IV }\end{array}$ & $\begin{array}{l}\text { Study with control } \\
\text { group, quantitative } \\
\text { approach }\end{array}$ & $\begin{array}{l}\text { Systematized coordination } \\
\text { of patient care, from initial } \\
\text { assessment and admission to } \\
\text { discharge or home care. } \\
\text { 1. Guidance on treatment and } \\
\text { diagnostic tests; } 2 \text {. Education } \\
\text { and advice; } 3 \text {. Nurses as } \\
\text { a reference of care in the } \\
\text { interdisciplinary team; } 4 \text {. } \\
\text { Management of administrative } \\
\text { processes that interfere } \\
\text { with clinical outcomes; } 5 \text {. } \\
\text { Continuous assessments, with } \\
\text { monitoring of symptoms, care } \\
\text { and progress. }\end{array}$ & $\begin{array}{l}\text { The experimental group had higher physical and } \\
\text { social conditioning, less financial expenses and } \\
\text { constipation than the control group. The length } \\
\text { of hospital stay was longer in the control group, } \\
\text { on average } 9.11 \text { days beyond the experimental } \\
\text { group. Significant differences found in quality of } \\
\text { life, satisfaction with care and length of hospital } \\
\text { stay between the experimental and control } \\
\text { groups suggest that care coordination provides } \\
\text { a useful model for the effective treatment of } \\
\text { cancer. }\end{array}$ \\
\hline $\begin{array}{l}\text { A Breast Navigator } \\
\text { Program: Barriers, } \\
\text { Enhancers, and Nursing } \\
\text { Interventions } \\
\text { Korber and } \\
\text { collaborators }^{(14)}\end{array}$ & $\begin{array}{l}2011 \\
\text { USA, } \\
\text { VI }\end{array}$ & $\begin{array}{l}\text { Qualitative study, } \\
\text { with focus group } \\
\text { and telephone } \\
\text { interviews } \\
\text { Breast cancer }\end{array}$ & $\begin{array}{l}\text { Breast Health Navigator } \\
\text { Program - the role of } \\
\text { navigators is to provide breast } \\
\text { cancer care, adapting to their } \\
\text { needs and cultures }\end{array}$ & $\begin{array}{l}\text { Navigators were seen as a link between team and } \\
\text { patient, mainly improving communication. The } \\
\text { management of symptoms was fundamental } \\
\text { for the success of coping with treatment, as } \\
\text { well as knowledge and preparation for pre- and } \\
\text { post-therapy effects. Navigators are the source of } \\
\text { suggestions, assessment, and management. Role } \\
\text { clearly integrated from beginning to end of care. } \\
\text { Source of information and support (emotional and } \\
\text { physical). }\end{array}$ \\
\hline $\begin{array}{l}\text { Do depressed newly } \\
\text { diagnosed cancer } \\
\text { patients differentially } \\
\text { benefit from nurse } \\
\text { navigation? } \\
\text { Ludman and } \\
\text { collaborators }^{(15)}\end{array}$ & $\begin{array}{l}2015 \\
\text { USA, } \\
\text { II }\end{array}$ & $\begin{array}{l}\text { Controlled } \\
\text { randomized clinical } \\
\text { trial } \\
\text { Breast, colon, and } \\
\text { lung cancer }\end{array}$ & $\begin{array}{l}\text { Intervention group: weekly } \\
\text { contacts with a nurse } \\
\text { navigator for } 16 \text { weeks }\end{array}$ & $\begin{array}{l}\text { Most participants had little or no depression at the } \\
\text { beginning of the study. Patients in the intervention } \\
\text { group had higher improvement scores than those } \\
\text { in usual treatment. The percentage of patients who } \\
\text { reported care problems increased with the severity } \\
\text { of depressive symptoms. Nurse navigators helped } \\
\text { newly diagnosed patients cope with treatment } \\
\text { barriers. }\end{array}$ \\
\hline
\end{tabular}




\begin{tabular}{|c|c|c|c|c|}
\hline $\begin{array}{l}\text { Title, } \\
\text { Authors }\end{array}$ & $\begin{array}{l}\text { Year, country, } \\
\text { level of evidence } \\
\text { (AHRQ) }\end{array}$ & $\begin{array}{l}\text { Outlining/ profile } \\
\text { of participants }\end{array}$ & Intervention & Outcomes/main conclusions \\
\hline $\begin{array}{l}\text { Impact of nurse } \\
\text { navigation on } \\
\text { timeliness of diagnostic } \\
\text { medical services in } \\
\text { patients with patients } \\
\text { newly diagnosed lung } \\
\text { cancer } \\
\text { Kunos, Olszewski, } \\
\text { Spinal(16) }\end{array}$ & $\begin{array}{l}2015, \\
\text { USA, } \\
\text { VI }\end{array}$ & $\begin{array}{l}\text { Retrospective } \\
\text { study } \\
\text { Lung cancer }\end{array}$ & $\begin{array}{l}\text { Coordination of diagnostic } \\
\text { procedures and consultations }\end{array}$ & $\begin{array}{l}\text { Navigation significantly increased the proportion } \\
\text { of patients undergoing more complex staging } \\
\text { and diagnostics. Reduced the time interval } \\
\text { between exams and medical consultations. } \\
\text { Significantly reduced the time for the first } \\
\text { treatment by } 19 \text { days. Improved overall access } \\
\text { and treatment opportunity. }\end{array}$ \\
\hline $\begin{array}{l}\text { The effects of } \\
\text { individually tailored } \\
\text { nurse navigation for } \\
\text { patients with newly } \\
\text { diagnosed breast } \\
\text { cancer: a randomized } \\
\text { pilot study } \\
\text { Mertz and } \\
\text { collaborators } \\
{ }^{(17)}\end{array}$ & $\begin{array}{c}\text { 2017, } \\
\text { Denmark, } \\
\text { II }\end{array}$ & $\begin{array}{l}\text { Randomized } \\
\text { controlled pilot } \\
\text { study } \\
\text { Breast cancer }\end{array}$ & $\begin{array}{l}\text { Navigation sessions based on } \\
\text { cognitive behavioral therapy } \\
\text { strategies (screening and } \\
\text { symptom counseling) }\end{array}$ & $\begin{array}{l}\text { Experimental group: significantly lower levels } \\
\text { of distress, anxiety and depression. There was } \\
\text { no significant effect on quality of life related } \\
\text { to physical or emotional health, or symptoms. } \\
\text { Significantly higher satisfaction with treatment } \\
\text { and rehabilitation and lower levels of distress, } \\
\text { anxiety and depression. Screening before } \\
\text { surgery, combined with navigation, can be } \\
\text { effective to identify and manage distress in the } \\
\text { most vulnerable patients. }\end{array}$ \\
\hline
\end{tabular}

Note: AHRQ - Agency for Healthcare Research and Quality.

The studies in this review showed results such as the effectiveness of health education, making the understanding, adaptation and coping of patients in the health and disease process better; improvement in assessment, management and continuity of care, and, consequently, improvement in the satisfaction of cancer patients; effective communication, with nurse navigators as communication links with the multidisciplinary team; improving access to health services, enabling treatment initiation.

Lee and collaborators ${ }^{(13)}$ demonstrated that hospital stay decreased considerably compared to the control group. Four studies $s^{(11-12,15,17)}$ (57\%) converged highlighting that the interventions performed by oncological navigators reduced the rates of distress, anxiety and/or depression. It is observed in two studies ${ }^{(11,14)}$ the relationship that navigators build with cancer patients, with health education strategies that empower them and help them understand the disease and adhere to treatment. Two studies ${ }^{(13,17)}$ differed on how to improve the quality of life of cancer patients navigated by nurses.

Through the studies selected in this review, the clinical outcomes of the navigation of cancer patients performed by nurses were evidenced, which are presented in full in Chart 3.

Chart 3 - Clinical outcomes of oncology patient navigation

- Decreased anxiety ${ }^{(11,17)}$

- Improvement in physical conditioning ${ }^{(11,13)}$

- Decreased distress ${ }^{(12,17)}$

- Improved symptom management and control(13,14) (e.g., less constipation)

- Decreased depression ${ }^{(15,17)}$

- Decreased fear ${ }^{(11)}$

- Improvement in quality and continuity of care ${ }^{(11)}$

- Decreased stress ${ }^{(12)}$

- Improvement in quality of life ${ }^{(13)}$

- Time interval reduction between exams and medical appointments ${ }^{(16)}$

- Time reduction to start treatment ${ }^{(16)}$

- Increase in the number of patients in staging and diagnostic test $\left.{ }^{5(16}\right)$

With regards to the level of evidence of publications, $57 \%$ were classified at level 6 , followed by $29 \%$ with level 2 and $14 \%$ with level 4 .

\section{DISCUSSION}

Studies related to navigation of cancer patients are on the rise, and the subject has been discussed in nursing practice; however, it is necessary to broaden the discussions regarding the clinical evidence of this model of professional performance. A greater number of publications were observed in the USA, and it is believed that this data may be related to the origin and implementation of navigation programs across the country ${ }^{(1)}$ as well as their inclusion in the American legislation and standards for health care accreditation ${ }^{(18)}$.

The study population consisted of patients with breast, lung, gastrointestinal and head and neck cancer, which is consistent with cancer incidence and prevalence in the worldwide population ${ }^{(19)}$. These areas are a priority for navigation expansion.

Nurse navigators are responsible for moving patients across the care continuum, promoting the integration of patients into the healthcare system ${ }^{(20-21)}$. Thus, the navigation of cancer patients has demonstrated benefits, such as less time for diagnosis and treatment, greater knowledge of the patient and family, better adherence to treatment and care ${ }^{(22)}$.

Effective communication is essential for a positive clinical outcome in patient navigation, since its absence can be a barrier to continuity of care ${ }^{(23)}$, findings that support the present review. Nurse navigators are seen as a connection that unites the healthcare team, patients and family members. With a clear and objective communication, they are able to guide, clarify, reinforce and validate the information that patients receives from different sources ${ }^{(14)}$.

It is noteworthy that health education is linked to communication. One of the goals of navigation is to provide information for patients and family members, involving them in their own treatments, as well as in decision-making, making care safe and effective ${ }^{(7)}$. When patients have sufficient information and knowledge, they are able to participate in the planning of their treatment, resulting in greater self-confidence and, consequently, an improvement in their quality of life ${ }^{(7,24)}$. 
Concerning the quality of life of cancer patients, there is no consensus among the studies ${ }^{(13,17)}$ in this review as to the benefit of performing navigation. However, other studies ${ }^{(5,11,25)}$ demonstrate that navigation can increase patient satisfaction, improving treatment adherence and reflecting on improving their quality of life.

Cancer treatment can trigger some symptoms, such as sleep disorders, fatigue, diarrhea, nausea and/or vomiting, which can affect both physically and psychologically patients, often causing delays or even interruption of treatment ${ }^{(26)}$. In a survey ${ }^{(14)}$ carried out on women diagnosed with breast cancer, the results showed that symptoms during treatment ranged from weak to severe; however, it was agreed that management by navigators was fundamental for coping with the disease and for the success and continuity of treatment. Another study ${ }^{(27)}$, carried out with patients with breast cancer, demonstrated the high level of patient satisfaction when monitored by nurse navigators. These findings support the effectiveness of patient-centered care performance.

Regarding the psychological and emotional aspects of cancer patients, there is a consensus among studies ${ }^{(11-12,15,17)}$ that the role of nurse navigators reduces patients' distress, anxiety and depression during treatment. Other studies ${ }^{(11-12,17)}$ indicate that there is a reduction in anxiety and depression when patients are more frequently followed up by nurse navigators, compared to those who are not included in this professional practice model. Ludman and collaborators ${ }^{(15)}$ demonstrated that navigation by nurses brought benefits to patients, influencing them positively. This influence was exercised both in patients who already had some psychological or emotional symptom at the time of diagnosis and in those who did not have any symptoms.

With regard to the average length of hospital stay, it was shown that patients who were not being monitored by nurse navigators remained in the hospital on average nine to 11 days in addition to those who were being monitored by navigators ${ }^{(13)}$. It is observed that navigation of patients results in a decrease in visits to the emergency departments of hospitals, shorter hospital stays and better use of resources, with patient guidance being a fundamental part of these data ${ }^{(28)}$.

A clinical outcome of patient navigation is related to the decrease in the time elapsed from diagnosis to the start of treatment ${ }^{(27)}$. One of the greatest difficulties for patients is access to specialized services for diagnosis definitions, generating delays that impact the start of treatment ${ }^{(29)}$. Nurse navigators play a key role in ensuring timely access to treatment and care for cancer patients ${ }^{(30)}$.

A study ${ }^{(28)}$ demonstrated that cancer patients who were included in the navigation program as part of the multidisciplinary care model had a significantly shorter time (15.15 days) between diagnosis and treatment initiation than those who were not followed up by nurse navigators, who started treatment in 42.93 days. The research ${ }^{(24)}$ that assessed the role of navigators in screening patients confirmed that they started treatment 10 days in advance, when compared with nonnavigated patients. Another study ${ }^{(16)}$ with significant results, developed with patients diagnosed with lung cancer, found a reduction in the time of the first cancer treatment in 19 days, i.e., navigation provided an efficient and favorable access. Without patient navigation, the staging required for diagnosis is less effective, resulting in additional consultations, delayed diagnostic tests and increased patient distress ${ }^{(28)}$.
Considering these studies, it is emphasized that the earlier the contact of nurse navigators with patients, the better the continuum of care in the entire health system ${ }^{(30)}$. It is also observed that the role of nurse navigators in oncology, in addition to being related to coordination of care, requires specific knowledge, skills and attitudes that allow them to influence systems and behaviors in health services; assess population's needs; promote advanced service planning; assess their barriers; provide education and resources; facilitate shared decision-making; identify gaps and strategies to meet continuum's needs ${ }^{(21)}$.

\section{Study limitations}

There are limitations related to databases, not considering studies indexed in other databases, as well as being limited to complete articles and available in full, which portrays part of the universe of studies. As for the weaknesses of this review, they refer to the level of evidence of the selected studies, which are mostly at level $\mathrm{VI}$, which denotes the need for nursing to conduct research with better levels of evidence, such as clinical trials.

\section{Contributions to nursing, health, and public policies}

It was found the importance of patient navigation performed by nurses as a model of continuum of care throughout the health system, with expressive clinical outcomes for cancer patients and their families. It is suggested that Brazilian oncology nursing develop a consensus, which presents the role of these professionals and all aspects that constitute the navigation processes, thus standardizing the model of performance.

\section{FINAL CONSIDERATIONS}

It is noteworthy that there is research that shows better clinical outcomes in cancer patients through navigation by nurses, throughout the continuum of health care. Some of the relevant aspects of patient navigation demonstrated by the studies were: decreased distress, anxiety, fear, stress, and depression; improvement in symptom control and management; improvement in physical conditioning; decrease in the time between screening, diagnosis and beginning of cancer treatment, leading, consequently, to better care conditions.

Nurse navigators' work provides patients with better conditions to understand the disease and adapt to treatment as well as multidisciplinary team work improvement in health services. Its role is visibly linked to coordination in the continuum of care, from treatment to end of life care.

It is expected that this review highlights the importance of nurse navigators' role in oncology and encourages professionals implementing navigation programs and developing new research.

\section{FUNDING}

This work was supported by the Coordination for the Improvement of Higher Education Personnel - Brazil (CAPES) - Financing Code 001. 


\section{REFERENCES}

1. Freeman HP, Rodriguez RL. History and principles of patient navigation. Cancer [Internet]. 2011 [cited 2019 Jul 12];117(suppl 15):3539-42. Available from: https://www.ncbi.nlm.nih.gov/pmc/articles/PMC4557777/pdf/nihms712733.pdf

2. Shejila CH, Mamatha SP, Fernandes DJ. Oncology nurse navigator programme: a narrative review. Nitte Univ J Health Sci[Internet]. 2015 [cited 2020 Jun 29];5(1):103- 7. Available from: http://nitte.edu.in/journal/december2014/ONNP.pdf

3. Wells KJ, Battaglia TA, Dudley DJ, Garcia R, Greene A, Calhoun E, et al. Patient navigation: state of the art or is it science? Cancer [Internet]. 2008 [cited 2020 Jun 29];113(8):1999-2010. Available from: https://www.ncbi.nlm.nih.gov/pmc/articles/PMC2679696/pdf/nihms-70696.pdf

4. Trevillion K, Singh-Carlson S, Wong F, Sherriff C. An evaluation report of the nurse navigator services for the breast cancer support program. Can Oncol Nurs J. 2015;25(4):409-21. https://doi.org/10.5737/23688076254409414

5. Carroll JK, Humiston SG, Meldrum SC, Salamone CM, Jean-Pierre P, Epstein RM, Fiscella K. Patients' experiences with navigation for cancer care. Patient Educ Couns[Internet]. 2010 [cited 2019 Jul 12];80(2):241-7. Available from: https://www.ncbi.nlm.nih.gov/pmc/articles/ PMC2891343/pdf/nihms165139.pdf

6. Paiva CJK, Cesse EAP. Aspectos relacionados ao atraso no diagnóstico e tratamento do câncer de mama em uma Unidade Hospitalar de Pernambuco. Rev Bras Cancerol[Internet]. 2015 [cited 2020 Jun 29];61(1):23-30. Available from: http://www1.inca.gov.br/rbc/n_61/v01/pdf/05artigo-aspectos-relacionados-ao-atraso-no-diagnostico-e-tratamento-do-cancer-de-mama-em-uma-unidade-hospitalar-de-pernambuco.pdf

7. Wagner EH, Ludman EJ, Aiello Bowles EJ, Penfold R, Reid RJ, Rutter CM, et al. Nurse navigators in early cancer care: a randomized, controlled trial. J Clin Oncol. 2014;32(1):12-8. https://doi.org/10.1200/JCO.2013.51.7359

8. Pautasso FF, Zelmanowicz AM, Flores CD, Caregnato RCA. Atuação do Nurse Navigator: revisão integrativa. Rev Gaúcha Enferm. 2018;39:e2017-0102. https://doi.org/10.1590/1983-1447.2018.2017-0102

9. Mendes KDS, Silveira RCCP, Galvão CM. Revisão integrativa: método de pesquisa para a incorporação de evidências na saúde e na enfermagem. Texto Contexto Enferm [Internet]. 2008 [cited 2019 Jun 12];17(4):758-64. https://doi.org/10.1590/S0104-07072008000400018

10. Melnyk BM, Fineout-Overholt E. Making the case for evidence-based practice. In: Melnyk BM, Fineout-Overholt E. Evidence-based practice in nursing \& healthcare: a guide to best practice. Philadelphia: Lippincott Williams \& Wilkins; 2005. p. 3-24.

11. Fillion L, de Serres M, Lapointe-Goupil R, Bairati I, Gagnon P, Deschamps M, et al. Implementing the role of patient-navigator nurse at a university hospital centre. Can Oncol Nurs J [Internet]. 2006 [cited 2019 Apr 29];16(1):11-7. Available from: http://www. canadianoncologynursingjournal.com/index.php/conj/article/view/296

12. Swanson J, Koch L. The role of the oncology nurse navigator in distress management of adult inpatients with cancer: a retrospective study. Oncol Nurs Forum. 2010;37(1):69-76. https://doi.org/10.1188/10.0NF.69-76

13. Lee T, Ko I, Lee I, Kim E, Shin M, Roh S, Yoon D, Choi S, Chang H. Effects of nurse navigators on health outcomes of cancer patients. Cancer Nurs. 2011;34(5):376-84. https://doi.org/10.1097/NCC.0b013e3182025007

14. Korber SF, Padula C, Gray J, Powell M. A breast navigator program: barriers, enhancers, and nursing interventions. Oncol Nurs Forum. 2011;38(1):44-50. https://doi.org/10.1188/11.onf.44-50

15. Ludman EJ, McCorkle R, Bowles EA, Rutter CM, Chubak J, Tuzzio L, et al. Do depressed newly diagnosed cancer patients differentially benefit from nurse navigation? Gen Hosp Psychiatry[Internet]. 2015 [cited 2019 Sep 4];37(3):236-9. Available from: https://www.ncbi.nlm.nih.gov/ pmc/articles/PMC4442728/pdf/nihms-668570.pdf

16. Kunos C, Olszewski S, Espinal E. Impact of nurse navigation on timeliness of diagnostic medical services in patients with newly diagnosed lung cancer. J Community Support Oncol. 2015;13(6):219-24. https://doi.org/10.12788/jcso.0141

17. Mertz BG, Dunn-Henriksen AK, Kroman N, Johansen C, Andersen KG, Andersson M, et al. The effects of individually tailored nurse navigation for patients with newly diagnosed breast cancer: a randomized pilot study. Acta Oncol. 2017;56(12):1682-9. https://doi.org/10.1080/028418 $6 X .2017 .1358462$

18. Hedlund N, Risendal, BC, Pauls H, Valverde PA, Whitley E, Esparza A, et al. Dissemination of patient navigation programs across the United States. J Public Health Manag Pract. 2014;20(4):E15-E24. https://doi.org/10.1097/phh.0b013e3182a505ec.

19. Global Cancer Organization. Cancer incidence and mortality statistics worldwide and by region. [Internet]. 2018 [cited 2019 Oct 25]. Available from: http://gco.iarc.fr/today/data/factsheets/cancers/39-All-cancers -fact-sheet.pdf

20. Lubejko BG, Bellfield S, Kahn E, Lee C, Peterson N, Rose T, et al. Oncology nurse navigation: results of the 2016 role delineation study. Clin J Oncol Nurs. 2017;21(1):43-50. https://doi.org/10.1188/17.CJON.43-50

21. Oncology Nursing Society. 2017 oncology nurse navigator core competencies[Internet]. 2017 [cited 2019 Oct 27]. Available from: https:// prod-www.ons.org/sites/default/files/2017-05/2017_Oncology_Nurse_Navigator_Competencies.pdf

22. Baileys K, McMullen L, Lubejko B, Christensen D, Haylock PJ, Rose T, et al. Nurse navigator core competencies: an update to reflect the evolution of the role. Clin J Oncol Nurs. 2018;22(3):272-281. https://doi.org/10.1188/18.CJON.272-281

23. Rosario M., Mckinney M., Alcott S. Lung screening programs and the effectiveness of the lung screening navigator. J Radiol Nurs. 2016;35(2):138-141. https://doi.org/10.1016/j.jradnu.2016.03.006 
24. Zibrik K, Laskin J, Ho C. Integration of a nurse navigator into the triage process for patients with non-small-cell lung cancer: creating systematic improvements in patient care. Curr Oncol. 2016;23(3):e280-3. https://doi.org/10.3747/co.23.2954

25. Skrutkowski M, Saucier A, Eades M, Swidzinski M, Ritchie J, Marchionni C, Ladouceur M. Impact of a pivot nurse in oncology on patients with lung or breast cancer: symptom distress, fatigue, quality of life, and use of healthcare resources. Oncol Nurs Forum. 2008;35(6):948-54. https://doi.org/10.1188/08.ONF.948-954

26. Koh C, Nelson JM, Cook PF. Evaluation of a patient navigation program. Clin J Oncol Nurs. 2011;15(1):41-8. https://doi.org/10.1188/11. CJON.41-48

27. Rohsig V, Silva P, Teixeira R, Lorenzini E, Maestri R, Saraiva T, et al. Nurse navigation program: outcomes from a breast cancer center in Brazil. Clin J Oncol Nurs. 2019;23(1):E25-E31. https://doi.org/10.1188/19.CJON.E25-E31

28. Muñoz R, Farshidpour L, Chaudhary UB, Fathi AH. Multidisciplinary cancer care model: a positive association between oncology nurse navigation and improved outcomes for patients with cancer. Clin J Oncol Nurs. 2018;22(5):E141-E145. https://doi.org/10.1188/18.cjon.e141-e145

29. Palmieri FM, DePeri ER, Mincey BA, Smith JA, Wen LK, Chewar DM, et al. Comprehensive diagnostic program for medically underserved women with abnormal breast screening evaluations in an urban population. Mayo Clin Proc. 2009;84(4):317-22. https://doi.org/10.1016/ S0025-6196(11)60539-9

30. Doerfler-Evans RE. Shifting paradigms continued - the emergence and the role of nurse navigator. J Thorac Dis. 2016;8(suppl 6):S498-S500. https://doi.org/10.21037/jtd.2016.04.03 